\title{
Metasomatic evolution of the SCLM beneath the Lunda Norte province (NE Angola)
}

\author{
Montgarri Castillo-Oliver ${ }^{1}$, William L. Griffin ${ }^{1}$, Joan Carles Melgarejo ${ }^{2}$, Salvador \\ Galí $^{2}$, Norman J. Pearson ${ }^{1}$, Vladimir Pervov ${ }^{\mathbf{3}}$ and Suzanne Y. O'Reilly ${ }^{\mathbf{1}}$ \\ ${ }^{1}$ ARC Centre of Excellence for Core to Crust Fluid Systems and GEMOC, Department of Earth and Planetary \\ Sciences, Macquarie University, NSW, Australia \\ ${ }^{2}$ Departament de Mineralogia, Petrologia i Geologia Aplicada, Facultat de Ciències de la Terra, Universitat \\ de Barcelona, Barcelona, Spain, joan.carles.melgarejo.draper@ub.edu \\ ${ }^{3}$ Sociedade Mineira de Catoca, Catoca, Lunda Sul, Angola
}

\section{Introduction}

The subcontinental lithospheric mantle (SCLM) is dynamic, continuously modified by partial melting, mantle metasomatism and asthenosphere upwelling. These depletion and refertilisation processes result in a heterogeneous and geochemically complex SCLM, composed of mantle domains differing in composition and thermal state. They also play a major role in the generation of diamond and its preservation in the lithospheric mantle prior to entrainment in the kimberlite, which makes it essential to understand these processes when assessing the diamond potential of a kimberlitic province.

In striking contrast with other cratons worldwide, the lithospheric mantle beneath Central Africa, and in particular the Congo Craton, is still poorly understood. The few studies carried out in the Congo Craton have shown that it is thicker and cooler than other cratons in Africa (O'Reilly et al. 2009; e.g. Begg et al. 2009; Robles-Cruz et al. 2012). Moreover, they suggest that the composition of the SCLM beneath the Congo Craton differs from other African cratons (Batumike et al. 2009; Robles-Cruz et al. 2012; Ashchepkov et al. 2012). Unfortunately, most of these works are based on the study of xenocrysts and megacrysts derived from mineral concentrates, resulting in a lack of petrographic information.

However, improving our current knowledge about the SCLM in the southwestern part of the Congo craton has become essential, since it contains one of the main diamondiferous kimberlite clusters in Africa. This work aims to provide a first insight into the metasomatic evolution of the SCLM beneath the Lunda Sul kimberlitic province (NE Angola), based on the petrographic and compositional characterisation of mantle xenoliths and large clinopyroxene megacrysts brought to the surface by the Catoca and Cat115 pipes.

\section{Petrography and composition of the mantle xenoliths}

Both coarse and porphyroblastic (sheared) garnet peridotites were sampled by these two kimberlites. As shown in fig. 1, sheared garnet peridotites are characterised by strong deformation of their pyroxenes, as well as by the occurrence of olivine and orthopyroxene neoblasts, with interstitial, finegrained clinopyroxene. This clinopyroxene is enriched in incompatible elements (Zr, Hf, LREE) with regards to the coarse Cr-rich diopside found in these xenoliths. These two garnet peridotite suites also differ in the major- and trace-element composition of their rock-forming minerals. The garnet in sheared peridotites is richer in $\mathrm{Cr}, \mathrm{Zr}$ and $\mathrm{Ti}$, while their olivine has lower \#Mg. Such compositional variations, as well as the $\mathrm{Zr} / \mathrm{Ga}$ and $\mathrm{Zr} / \mathrm{Y}$ ratios in garnet, are similar to patterns seen in most cratons worldwide (Griffin et al. 1999). However, the mineral modes of the studied xenoliths significantly differ from those described in the Kaapvaal craton and are more comparable to those reported in the Slave craton or in oceanic peridotites.

The eclogites sampled by the Catoca kimberlite have textural and compositional features typical of both type I and type II eclogites as defined by McCandless and Gurney (1989) and Gréau et al. (2011), which suggests that this classification may not be applicable to the mantle eclogites of the Lunda Sul province. Two groups of eclogites (i.e., high- and low-Mg) were identified, which is consistent with previously published studies of eclogites from this kimberlite cluster (Nikitina et al. 2014). 
Typical metasomatic phases (phlogopite, Cr-diopside, ilmenite, amphibole) have been identified in several of these xenoliths. Highly-metasomatised xenoliths typically include larger amounts of these minerals, which are accompanied by amphibole, apatite, chromite and rutile. Supergene alteration of some of these xenoliths resulted in the occurrence of phases typical of oxidising environments (barite, celestine and calcite).

Geothermobarometric calculations reveal that the SCLM beneath the Lundas kimberlitic province is composed of two clearly distinct garnet-peridotite layers: a shallow, low-T, coarse peridotite layer (820$1080^{\circ} \mathrm{C}$ at $\left.30-40 \mathrm{kbar}\right)$ and a deep, high-T, porphyroclastic (sheared) peridotite layer $\left(1160-1220^{\circ} \mathrm{C}\right.$ at 46-52 kbar). An intermediate layer dominantly composed of low-Mg eclogites $\left(1040-1140^{\circ} \mathrm{C}, 43-49\right.$ kbar) is located between the two garnet-peridotite suites. Unfortunately, our current data are still insufficient to explain the origin of this structure, which could be either explained by subduction stacking or by upwelling and intrusion of mafic magmas.
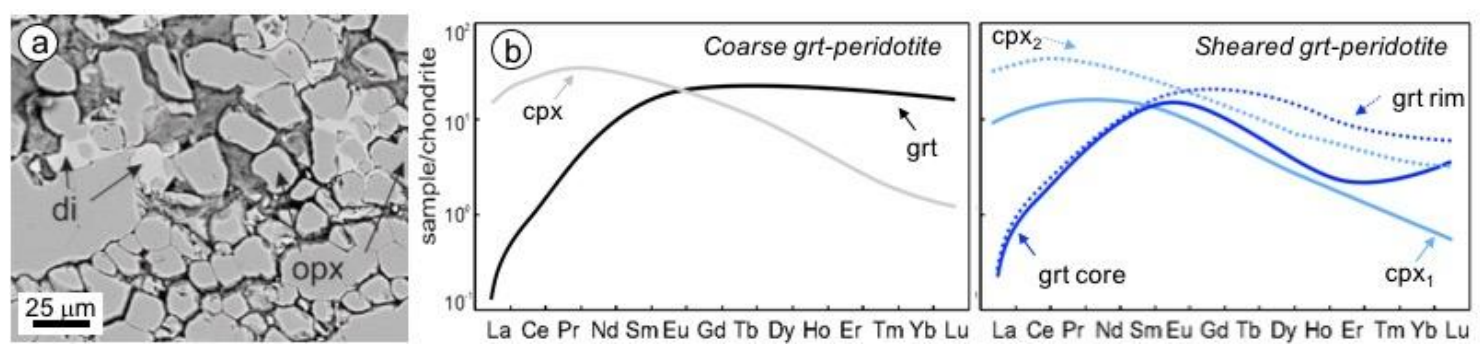

Fig.1. a) BSE image of a sheared garnet-peridotite showing the occurrence of a second generation of interstitial diopside (di) between the orthopyroxene neoblasts (opx). b) Chondrite-normalised REE patterns for garnet (grt) and clinopyroxene (cpx) in coarse and sheared garnet-peridotites. Only one generation of clinopyroxene and garnet is found in the coarse peridotites, whereas compositional differences between the core and the rim of garnets, and the coarse- and fine-grained clinopyroxenes, are a characteristic feature of the sheared peridotites.

\section{Mantle metasomatism in the SCLM in Lunda Sul: a multi-stage process}

Complex, multi-stage metasomatic processes were identified in the SCLM beneath the Lunda Sul kimberlitic province, which involved both modal and cryptic/stealth metasomatism. The study of the trace element composition of garnet and clinopyroxene revealed that the low-T and high-T garnet peridotite suites were modified by compositionally different metasomatic melts that percolated through the lithospheric mantle at different times (Fig.1b). Although there is only a limited number of xenoliths available, a possible model of the metasomatic evolution of the SCLM in NE Angola could be proposed.

Our data suggest that the upper SCLM was first metasomatised by silicate melts related to the ascent of asthenospheric melts. This first metasomatic episode could thus be linked either to subduction of oceanic lithosphere or to the ascent of a mantle plume that led to the current layered SCLM. It resulted in the introduction of garnet $( \pm \mathrm{cpx})$ into the originally depleted Archean lithosphere.

Subsequently, a high-T metasomatic event modified the composition of the garnet peridotites located close to the new lithosphere-asthenosphere boundary. The melts involved in this process were of a mixed nature (carbonatite-silicate) and were responsible for the refertilisation of this layer with both clinopyroxene and garnet.

Percolative fractional crystallisation of these carbonate-silicate melts would explain the late formation of clinopyroxene with a carbonatitic trace-element signature and phlogopite in the upper layer of the SCLM. The differences in the calculated melts in equilibrium with garnet and clinopyroxene in the coarse garnet peridotites is consistent with different metasomatic events for both phases. This carbonatite-related metasomatism took place shortly prior to kimberlite eruption. Alternatively, if clinopyroxene was previously present, cryptic carbonatitic metasomatism could be responsible for its current composition. 
The latest metasomatic episode is defined by the crystallisation of fine-grained pyroxene along fractures and grain boundaries in eclogites, clinopyroxene megacrysts and deep garnet-peridotites. The new clinopyroxene is typically more enriched in $\mathrm{Ti}, \mathrm{Ca}, \mathrm{REE}$ and $\mathrm{Nb}$, but commonly depleted in $\mathrm{Na}$, and crystallised together with a second generation of phlogopite. This metasomatism has been linked to kimberlite eruption.

\section{Conclusions}

A detailed petrographic and compositional characterisation of 25 mantle xenoliths revealed a complex metasomatic evolution of the SCLM beneath the Lundas kimberlitic province (NE Angola). The shallow and the deeper parts of the lithospheric mantle were modified by different metasomatic processes at different times. The model proposed here includes several episodes of mantle refertilisation after the early Archean depletion, involving silicate, carbonate-silicate and carbonatite-related fluids, as well as late kimberlite-related metasomatism. All these processes significantly modified the composition of the diamond indicator minerals (i.e., garnet and clinopyroxene) and caution should be taken when using them to assess the diamond grade of a kimberlite.

\section{References}

Ashchepkov IV, Rotman a. Y, Somov SV, et al (2012) Composition and thermal structure of the lithospheric mantle beneath kimberlite pipes from the Catoca cluster, Angola. Tectonophysics 530-531:128-151. doi: 10.1016/j.tecto.2011.12.007

Batumike JM, Griffin WL, O'Reilly SY (2009) Lithospheric mantle structure and the diamond potential of kimberlites in southern D.R. Congo. Lithos 112:166-176. doi: 10.1016/j.lithos.2009.04.020

Begg GC, Griffin WL, Natapov LM, et al (2009) The lithospheric architecture of Africa: Seismic tomography, mantle petrology, and tectonic evolution. Geosphere 5:23-50. doi: 10.1130/GES00179.1

Gréau Y, Huang J-X, Griffin WL, et al (2011) Type I eclogites from Roberts Victor kimberlites: Products of extensive mantle metasomatism. Geochim Cosmochim Acta 75:6927-6954. doi: 10.1016/j.gca.2011.08.035

Griffin WL, Fisher NI, Friedman J, et al (1999) Cr-Pyrope Garnets in the Lithospheric Mantle. I. Compositional Systematics and Relations to Tectonic Setting. J Petrol 40:679-704. doi: 10.1093/petroj/40.5.679

McCandless TE, Gurney JJ (1989) Sodium in garnet and potassium in clinopyroxene: criteria for classifying mantle eclogites. In: Ross J, Jacques AL, Ferguson J, Green DH (eds) Kimberlites and Related rocks. pp 827-832

Nikitina LP, Korolev NM, Zinchenko VN, Felix JT (2014) Eclogites from the upper mantle beneath the Kasai Craton (Western Africa): Petrography, whole-rock geochemistry and $\mathrm{UPb}$ zircon age. Precambrian Res 249:13-32. doi: 10.1016/j.precamres.2014.04.014

O'Reilly SY, Zhang M, Griffin WL, et al (2009) Ultradeep continental roots and their oceanic remnants: A solution to the geochemical "mantle reservoir" problem? Lithos 112:1043-1054. doi: 10.1016/j.lithos.2009.04.028

Robles-Cruz S, Melgarejo J, Galí S, Escayola M (2012) Major- and Trace-Element Compositions of Indicator Minerals that Occur as Macro- and Megacrysts, and of Xenoliths, from Kimberlites in Northeastern Angola. Minerals 2:318-337. doi: 10.3390/min2040318 